\title{
INFORMATION TECHNOLOGY (IT) IMPROVEMENT AT PT SUMBER ALFARIA TRIJAYA
}

\author{
Marisa Karsen \\ Information Systems Department, School of Information Systems, Binus University \\ Jl. K.H. Syahdan No. 9, Palmerah, Jakarta Barat 11480 \\ marisa_karsen@binus.ac.id; marisakarsen@yahoo.com
}

\begin{abstract}
Retail industry is the second largest industry after agricultural industry in terms of employment absorption in Indonesia. The situation of the quite dynamic retail industry is marked by the development of modern retail trade and it impacts on traditional markets and suppliers. PT Sumber Alfaria Trijaya, known as Alfamart is one of the best retail company in Indonesia. It already uses Supply Chain Management and B2B to support their operations. Alfamart also has its own website which provides information about products, outlets, services, and promo. This research discusses about IT improvement. The purpose of this paper is to improve Alfamart IT performance and make innovation on the IT to increase customer satisfaction. The methodology used is defining the problem, measure, analyst problem, improvement required by Alfamart, and control to monitor the implementation. Problems are identified using SWOT analysis, problem clarification, and business model canvas. Analyzing the problems, solution hypotheses and IT improvement are recommended for Alfamart.
\end{abstract}

Keywords: IT improvement, problem analysis, SWOT analysis, IT recommendation

\begin{abstract}
ABSTRAK
Industri ritel merupakan industri terbesar kedua setelah industri pertanian dalam hal penyerapan tenaga kerja di Indonesia. Situasi industri ritel yang cukup dinamis ditandai oleh perkembangan perdagangan ritel modern yang berdampak pada pasar tradisional dan pemasok. PT Sumber Alfaria Trijaya, yang dikenal sebagai Alfamart, merupakan salah satu perusahaan ritel terbaik di Indonesia. Alfamart sudah menggunakan Supply Chain Management dan B2B untuk mendukung operasi mereka. Alfamart juga memiliki website sendiri yang menyediakan informasi tentang produk, outlet, layanan, dan promo. Penelitian ini membahas tentang perbaikan TI. Tujuanya adalah untuk meningkatkan kinerja TI Alfamart dan membuat inovasi TI demi meningkatkan kepuasan pelanggan. Metodologi yang digunakan adalah mendefinisikan masalah, ukuran, analisis masalah, perbaikan diperlukan oleh Alfamart, dan kontrol untuk memonitor pelaksanaannya. Masalah diidentifikasi menggunakan analisis SWOT, klarifikasi masalah, dan kanvas model bisnis. Setelah menganalisis masalah, hipotesis dan solusi perbaikan TI dapat diusulkan untuk Alfamart.
\end{abstract}

Kata kunci: perbaikan TI, analisis masalah, analisis SWOT, usulan TI 


\section{INTRODUCTION}

Retail industry is a strategic one, since it is the second largest industry after agricultural industry in terms of employment absorption in Indonesia. The situation of the quite dynamic retail industry is marked by the development of modern retail trade and it impacts on traditional markets and suppliers. The modern retail trade growth is inversely proportional to the traditional market. On the other hand, the increasing number of modern retailers makes suppliers' bargaining position increasingly weak. It is characterized by the increase of the trading terms considered burdensome to suppliers' position. Up to December 2011, Modern Trade has reached 42.9\% of Total Indonesia's sales (excl.cigarette) (Figure 1).

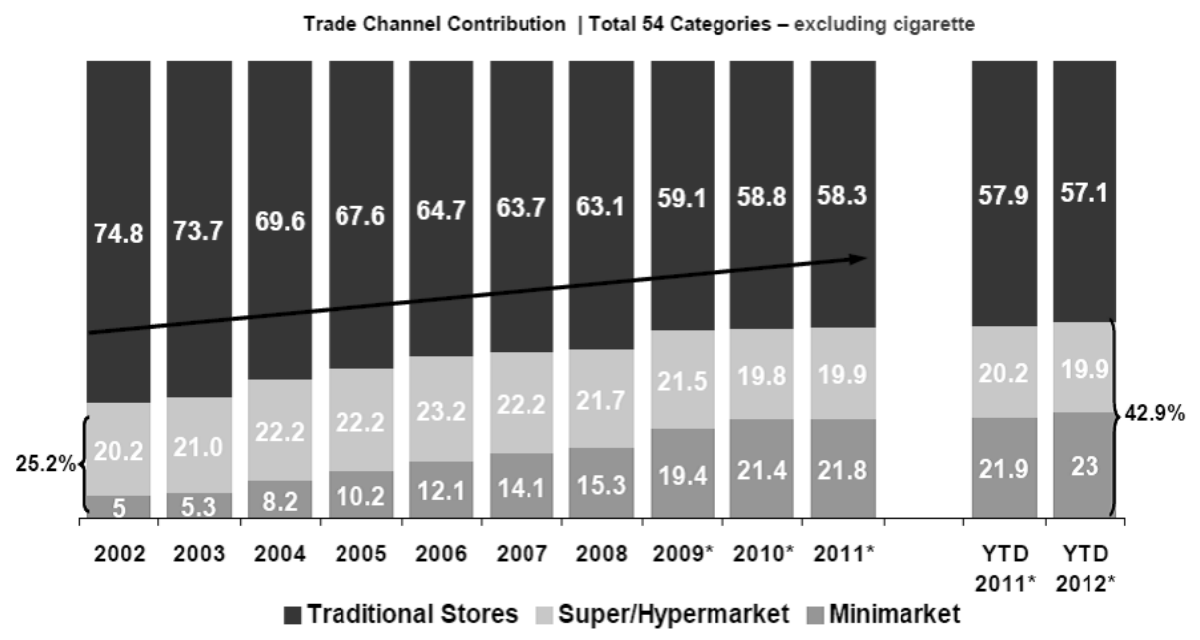

Figure 1 Trade Channel Cotribution (Source: Nielsen Retail Audit)

There are many modern retail trade in Indonesia, such as Indomaret, Ace Hardware, Carrefour, Alfamart, Alfa Midi, Seven Eleven, Circle-K, etc. Since customers always want to make transactions faster and easier, most of retail trade now already collaborate with banks to create cashless payment using debit card, prepaid card, and credit card. Many of their outlets already use POS (point of sales) terminal for the cashier and already use ERP to connect between branches and headquarter. That's why IT has made a significant contribution to modern retail trade.

Established in 1989 by Djoko Susanto and Family, PT Sumber Alfaria Trijaya started as a consumer goods trading and distribution business, then in 1999 entered into retail sector. In 2002 the Company started an exponential expansion through acquiring 141 Alfa Minimart stores and bring a new name, i.e 'Alfamart'. Its vission is to be Indonesia's largest and globally competitive widely owned retail distribution network that empowers small entrepreneurs and fulfills customer needs and expectations. The vision is expected to be achived through several mission,they are: (1) to satisfy customer needs and expectations by focusing on high quality products and services; (2) to implement ethical business practices, to be the best in all of our actions; (3) to develop entrepreneurial spirits and skills in the Company and the society; (4) to develop a reliable, healthy and growing organization which benefits all stakeholders.

Alfamart already uses Supply Chain Management and B2B to support their operations. Alfamart also has own website that provide information about their products, outlets, services, and promo. 
IT has become an enabler for effective supply chain management, because of technology and software - including such IT tools as Enterprises Resources Planning (ERP) systems (including forecast software), barcodes, Radio Frequency Identification (RFID), and point-of-sales data. Companies can track and locate inventory through its supply chain, which enables them to locate inventory somewhere other than their own facility, and control it remotely or have someone else control it (Taylor, 2011).

Information System is defined more broadly as the combination of technology (the "what"), people (the "Who"), and process (the "How") that an organization uses to produce and manage information (Pearson \& Saunders, 2009).

In this paper, we would like to add something new for technology, especially from customer's side. The main goal presented in this research is to improve Alfamart IT performance and make innovation in IT to increase customer satisfaction. This paper has the following objectives: (1) to make strong IT infrastructure to support Alfamart activity; (2) to increase service to customer with always make every goods are available.

\section{METHODS}

The problem solving process can be divided in different ways and the stages have been given various labels. This has been done to make it easier to understand but how it is divided and the labels that are used are not important. To be a successful problem solver you need to understand what the stages involve and follow them methodically whenever you encounter a problem. The stages of problem solving are (Figure 1):
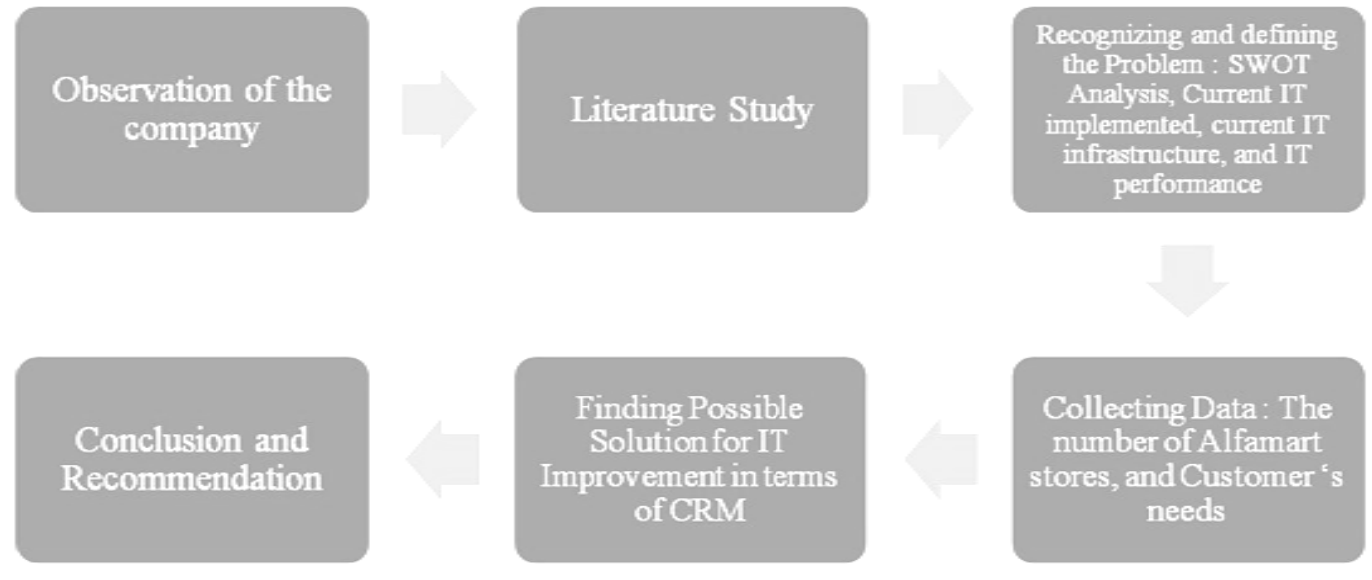

Figure 2 Methodology (source: personal analysis)

\section{Company Observation}

First step to do problem solving is make observation to the company to know real condition, what was happened and kinds of related problem. On this case, the observation is scoped in several Alfamart stores in Karang Tengah-Ciledug which are directly related with Alfamart Operation. After that, we obtain the data from Alfamart annual report and start to analyze the data. 


\section{Literature Study}

Having observations on the stores condition, comparison is made between the real situation with ideal condition in the theories retrieved from book, internet, and other media related to the scoped of the problems.

\section{Recognizing and Defining the Problem}

Obviously, before any action can be taken to solve a problem, we need to recognize that a problem exists. SWOT Analysis is used to analyze the details about Alfamart's strength, weakness, opportunities, and threats. After that, the best recommendations for Alfamart can be proposed.

From the observation to the company, there are some issues that can be discussed. In this case, excellence IT Improvement for CRM is used as the problem solving to be implemented by the company.

\section{Collecting Data}

Data are collected from Alfamart Annual Report and Alfamart website. Data collected include: (1) general data that includes company history, vision and mission into the future, and the number of stores; (2) customer needs to make IT improvement in the future, so Alfamart could build new CRM to meet customer needs.

\section{Finding Possible Solution}

Through an analysis problem process, this phase focuses on creating solutions and making project design to increase IT performance. In addition to ensuring continued success, this phase also involves monitoring for new problems created by system changes.

\section{Conclusion and Recommendation}

After make analysis and find the alternative solution for the problem, conclusion and recommendation can be made which represents all of the results in the study. Conclusion should maked to make more understanding about the goals and ensure the problem analysis will meet the right solution.

\section{RESULTS AND DISCUSSION}

\section{Current IT Implementation at Alfamart}

\section{Strong Supply Chain Management}

Alfamart already implement supply chain management from supplier to retail stores, both on regular and franchise store, and also has Customer Loyalty Program which generates date of customer spending pattern. Alfamart Distribution Centers already uses integrated system and IT driven which include Order, Receiving, storage, Picking, and Delivering. Distribution Centers work seven days a week to ensure stock fulfilling in all of Alfamart stores. These conditions are based on Alfamart Annual Report 2011 (Figure 3). 


\section{Distribution Centers}

Distribution Centers (DC) is the heart of operating system in Alfamart. Each DC uses hub and spore network to connect with all Alfamart Stores. This comprehensive IT system determines the inventory needs of each store. Each DC is uniquely designed for Alfamart special needs and is served on average of 300 stores.

\section{Finance Operation}

Alfamart already uses Internet Banking (KlikBCA Bisnis) to support payroll for employees and make payments to suppliers with mass transfer system called payroll system and AutoCredit. Using KlikBCA Bisnis, all transaction was created by maker, approve by approver and released by releaser. KlikBCA Bisnis uses Virtual Private Network (VPN) to give best security system for customers.

\section{B2B for Suppliers}

To establish better cooperation with all suppliers, Alfamart implements Business to Business (B2B, Figure 3 dan 4) for suppliers which can be used to see List of Purchase Orders from Alfamart Stores, return of goods, service level, etc. Every supplier has their own user name and password to use B2B feature.

\section{Customer Loyalty Program and Payment Methods}

Alfamart has loyalty program called Kartu AKU (Figure 5) which has more than 3.1 million members of which $50 \%$ are active members. Member benefit includes HematKu (MySaving), SpecialKu (MySpecial), and HadiahKu (MyPrize). Points are accumulated for every purchase and can be redeemed periodically. To create more functions in Kartu AKU, Alfamart cooperate with BCA and BNI to provide membership card which can be used as payment method (prepaid card). Every Alfamart Store already receive cash less payment method with using Electronic Data Capture (EDC) Machine to receive payment from Debit Card, so with this cooperation, Alfamart could give best service to customers that can used Prepaid Card for their transactions.

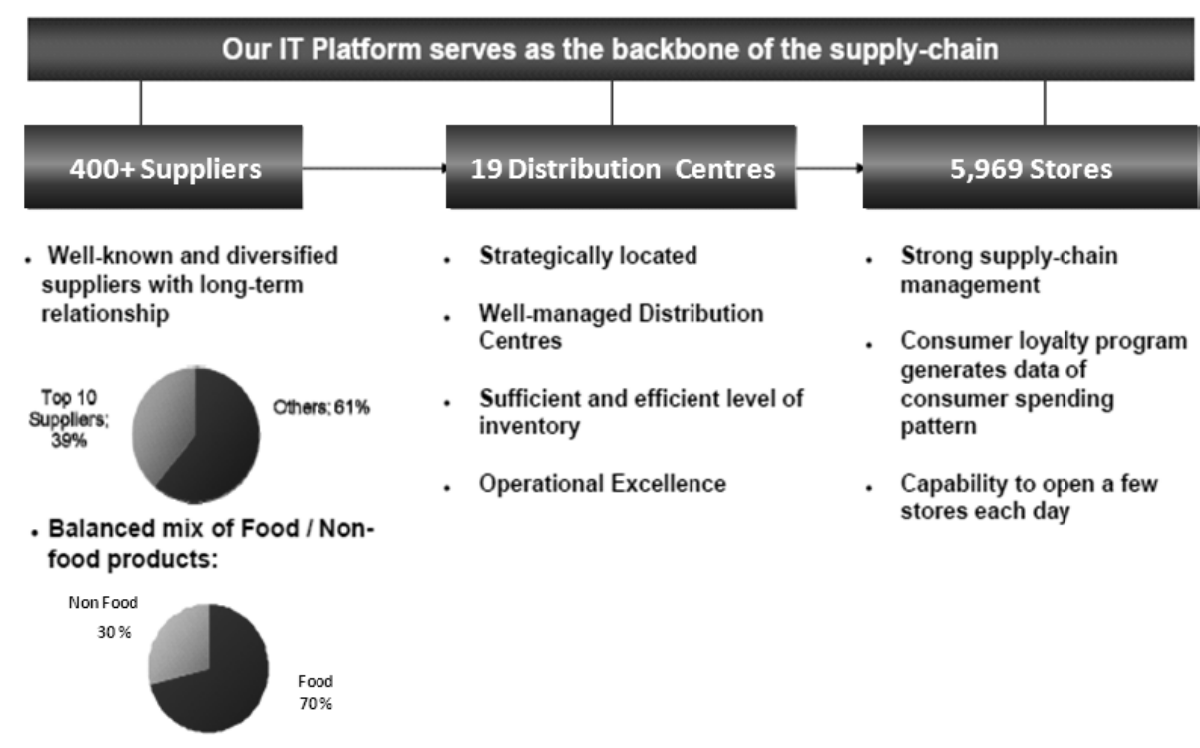

Figure 3 Alfamart IT Platform (Source: Alfamart Annual Report 2011). 


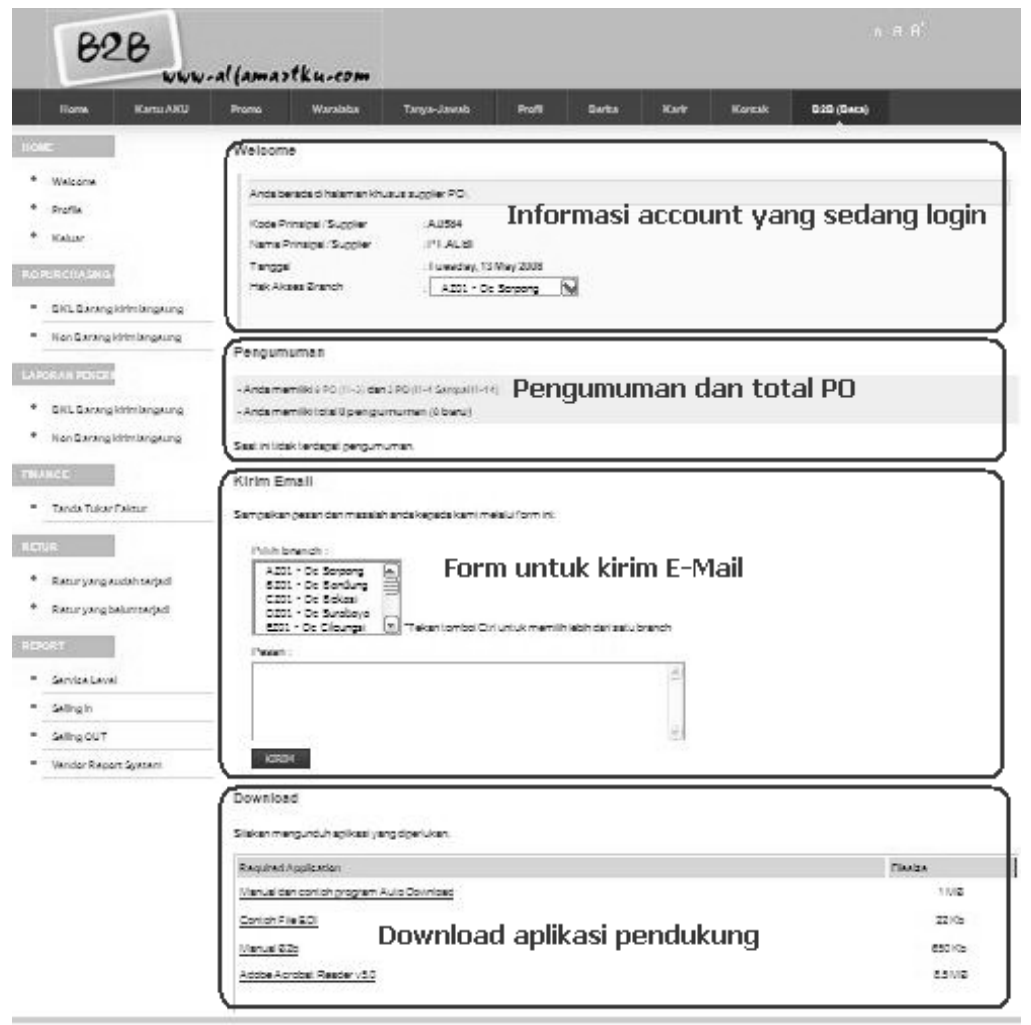

Figure 4 Alfamart B2B for Supplier (Source: Alfamart Website).

Two type of membership card and also prepaid card, as follows: (1) A Card Flazz (Figure 6) is Alfamart Member Card launched on May 15, 2010, cooperated with Flazz BCA. A Card Flazz can be used for transaction not only in all Alfamart Stores, Alfamidi, or Alfexpress, but also in all Flazz Merchant, such as restaurant, Saloon, bookstore, etc (Jabodetabek and Bandung only); (2) Kartu Aku BNI is Alfamart Member Card launched on Jan 1, 2010, cooperated with BNI Bank. Kartu Aku BNI can be used for transaction in all Alfamart Stores, Alfamidi, or Alfexpress (Jabodetabek only).

\section{Website}

Alfamart has a website that provides information about products, store locations, promo, customer loyalty program, event, etc at http://www.alfamartku.com/ and also a corporate website at http://corporate.alfamartku.com/. In this website, we can see a lot of information about Alfamart because the website is user friendly and easy to understand.

\section{SWOT Analysis}

The internal factors are strength and weakness, and the external factors are opportunity and threat. Strength: (1) network with a lot of stores (5,969 stores); (2) High Technology support (SCM, POS, Flazz Card). Weakness: (1) lack of inventory monitoring system between Alfamart stores; (2) regular service. Opportunities: (1) fast growing of IT in the market; (2) building excellent IT infrastructure. Threat: competitors (due to the faster growing of retail industry). 


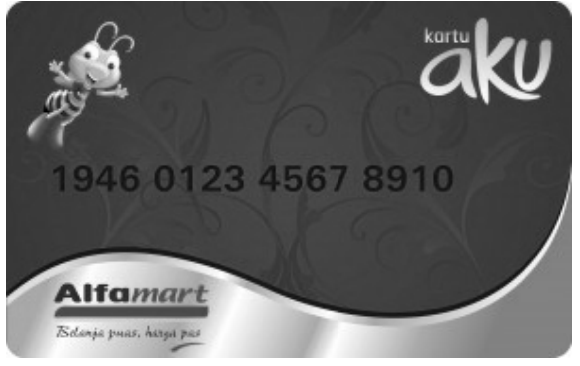

Figure 5 Kartu Aku.

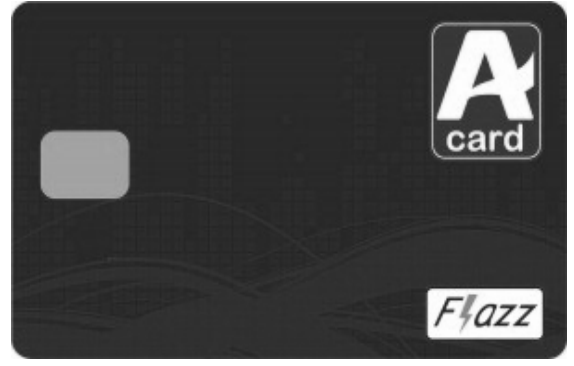

Figure 6 A Card Flazz.

\section{Problems in Existing Mechanism}

One example of problem happens at an Alfamart store is described as follows: A customers wanted to buy a product that is not displayed in one store. The customer then asked the employee or cashier about the stock. The employee or cashier said that the product is out of stock and they didnot know whether the same product was available or not at other Alfamart stores (even the nearest one). In this case, customer was not satisfied with Alfamart's service because Alfamart could not give more information about the product, and the customer needed to find the product availability in other store by his/herself. This situation is illustrated on Figure 7.

\section{IT Recommendation for Alfamart}

According to the future strategis of Alfamart in improving profitability which are: (1) adopting new technology to improve efficiency; (2) improving margin through value added services and private label, Alfamart needs to give better services for customers, not only from customer loyalty program, but also by concern in customer's demand. In this case, we would like to recommend "Online Customer Tracking Inventory System" using e-commerce through Alfamart website. This can be one of the Alfamart's Customer Relationship Management Program.

\section{Future Mechanism}

Using “Online Customer Tracking Inventory System”, customers can find the stock of products and find the store location at Alfamart Stores through Alfamart website, before they go to the store for buying the products. The future mechanism is as follows (Figure 8): Customer open Alfamart website at http://www.alfamartku.com/ and click on "Layanan" menu. After that, select Store Locations. And then customers input the product that they want to buy. The Alfamart System will check the availability of the product in that store. If the product is out of stock, the system will help customer to find another Alfamart store near the location. After that, customer can go to the Alfamart store to buy the product.

\section{Benefits}

Some benefits of implementing this technology are maximizing website value, increasing customer satisfaction, estabishing better inventory management.

\section{Implementation}

This kind of technology can be implemented at all Alfamart stores in Indonesia, because this technology use Alfamart website that can be accessed at almost all places in Indonesia. Since the inventory system already exists in Alfamart, adding tracking system for customers does not need 
radical change on IT. It only needs an additional connection between e-commerce and inventory system. We believe this new mechanism will bring more value to all Alfamart customers and increase customer satisfaction at Alfamart.

\section{Risk Management}

To implement new project of the system, we should consider about risk management in the company. In this case, Alfamart need to prepare the security system to mitigate the risk. Every customer that wants to use online tracking system should be registered as member of Kartu Aku and have their own username and password. The system also protects all stock data and only presents the information of the items searched by customers.

\section{Performance Measurement}

This system implementation will be reviewed every year with the increase number of Alfamart customers and Customer Satisfaction Rating from independent research company. This project should include several people, as follows: (1) IT officers, such as web designer to design the user interface, and programmer to create application, connect the program and network; (2) inventory officer to maintain the latest stock in every Alfamart store and update price for every item purchased; (3) customer service officer to respond customer request of complain, especially if the website can not work well.

Customer

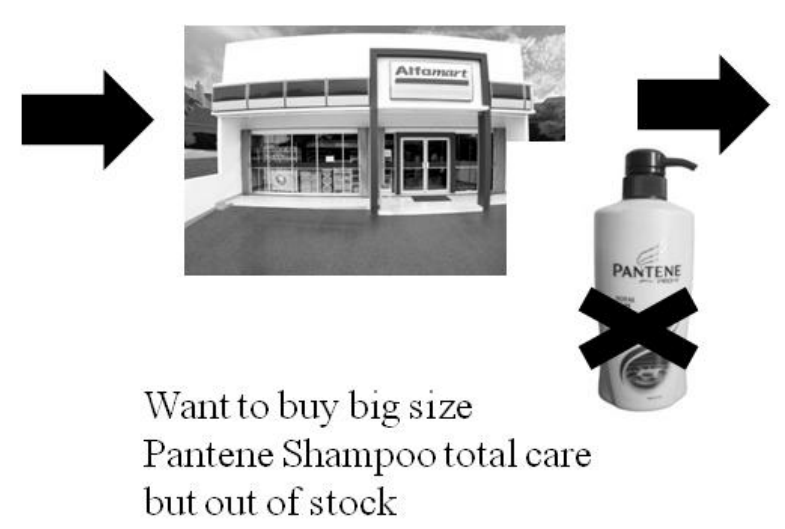

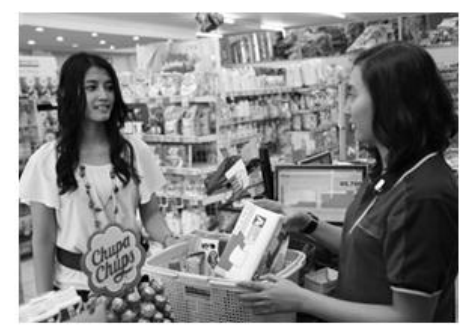

Ask to the cashier but just get "out of stock" answer

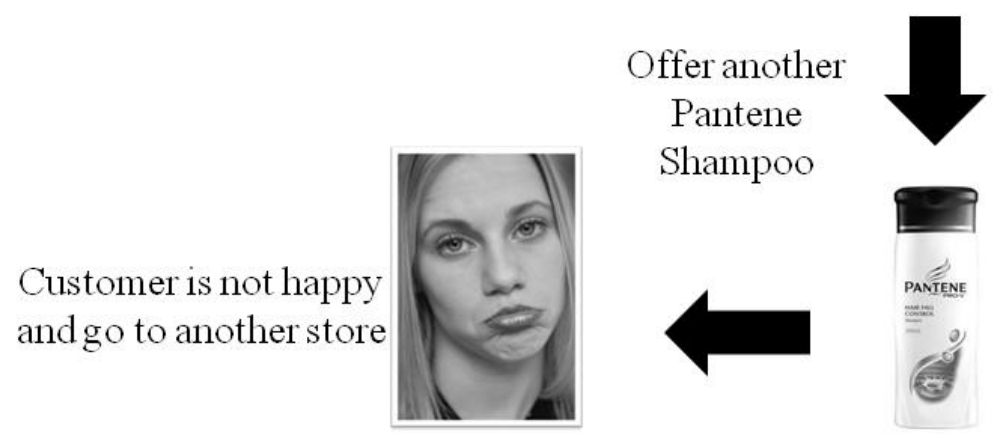

Figure 7 Alfamart Existing Mechanism (Source: personnal research) 


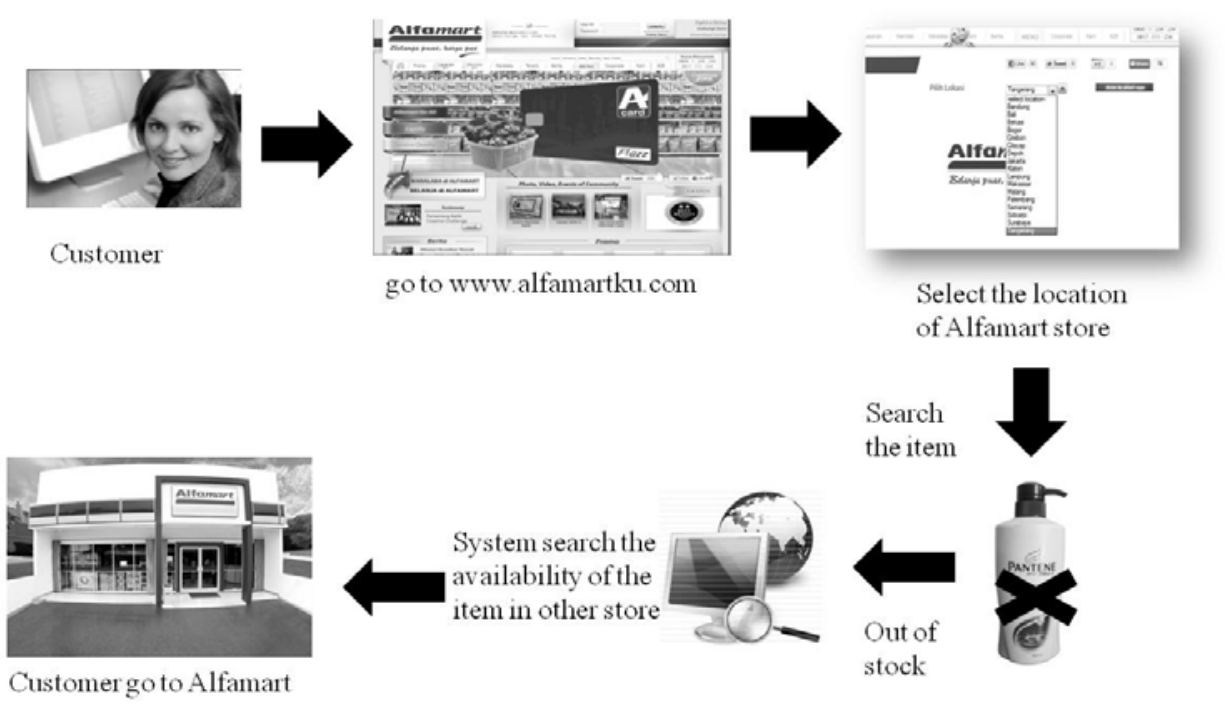

Figure 8 Alfamart Future Mechanism (source: personnal research)

\section{CONCLUSION}

Having a research on IT implementation at PT Sumber Alfaria Trijaya (Alfamart), we can actually conclude that the IT functions are needed to be taken into consideration in order to maximizing the IT services and performance to be more efficient and effective for Alfamart customers. With "Online Customer Tracking Inventory System”, Alfamart is believed able to defeat the competitors. Several significant IT improvements \& implementations with cost saving result in better outlook of Alfamart services.

"Online Customer Tracking Inventory System" is recommended for better inventory monitoring system, because we know that nowadays competitors can easily create the same thing and benchmark this strategy, so Alfamart needs to make fast movement in implementing this new strategy. With continuous improvement on IT, Alfamart can achieve its vision to be Indonesia's largest and globally competitive widely owned retail distribution network that empowers small entrepreneurs and fulfills customer needs and expectations, and win competition in the retail industry.

\section{REFERENCES}

Alfamart Website. (2012). Diakses dari http://www.alfamartku.com.

Alfamart Corporate Website. (2012). Diakses dari: http://corporate.alfamartku.com/.

Pearson, K. E., \& Saunders, C. S. (2009). Strategic Management Information Systems. Florida: John Willey \& Sons.

Taylor, R. A. (2011). Operations Management. New Jersey: John Wiley \& Sons. 